\title{
Occupational asthma due to manual metal-arc welding of special stainless steels
}

\author{
T. Hannu*, R. Piipari*, H. Kasurinen”, H. Keskinen*, M. Tuppurainen* and T. Tuomi*
}

ABSTRACT: Occupational asthma (OA) can be induced by fumes of manual metal-arc welding on stainless steel. In recent years, the use of special stainless steels (SSS) with high chromium content has increased.

This study presents two cases of OA caused by manual metal-arc welding on SSS. In both cases, the diagnosis of OA was based on respiratory symptoms, occupational exposure and positive findings in the specific challenge tests.

In the first case, a 46-yr-old welder had experienced severe dyspnoea while welding SSS (SMO steel), but not in other situations. Challenge tests with both mild steel and stainless steel using a common electrode were negative. Welding SSS with a special electrode caused a delayed $37 \%$ drop in forced expiratory volume in one second (FEV 1 ). In the second case, a 34-yr-old male had started to experience dyspnoea during the past few years, while welding especially SSS (Duplex steel). The workplace peak expiratory flow monitoring was suggestive of OA. Challenge tests with both mild steel and stainless steel using a common electrode did not cause bronchial obstruction. Welding SSS with a special electrode caused a delayed $31 \%$ drop in FEV1.

In conclusion, exposure to manual metal-arc welding fumes of special stainless steel should be considered as a new cause of occupational asthma.

KEYWORDS: Challenge test, chromium, manual metal-arc welding, occupational asthma, stainless steel

$\mathbf{R}$ espiratory effects associated with welding include metal fume fever, chronic bronchitis, lung function abnormalities and occupational asthma (OA) [1, 2]. OA has previously been reported in workers exposed to manual metal-arc welding (hereafter termed welding) on stainless steel [3] and on aluminium [4]. Moreover, KESKINEN et al. [5] have described a case of $\mathrm{OA}$ in a welder who welded on steel painted with paint containing chlorendic anhydride.

Many stainless steel subclasses have been developed to be resistant in different environments and working conditions. High-alloyed austenitic steel, such as $254 \mathrm{SMO} \AA$ and austenitic-ferritic (Duplex) steel, offer good resistance to corrosion and pitting. Both of these special stainless steels (hereafter termed special steels) have a high chromium content.

The present study describes two patients who developed asthmatic reactions when exposed to welding fumes of special steels.

\section{MATERIALS AND METHODS}

Flow-volume spirometries were performed with a pneumotachograph spirometer connected to a microcomputer (Medicro MR909; Medikro, Kuopio, Finland), and reference values from VILJANEN [6] were used. Bronchial hyperresponsiveness to histamine was assessed using the method of SoviJÄrvi et al. [7]. Peak expiratory flow (PEF) measurements at home and at the workplace were performed according to the method of BURGE [8].

Skin-prick tests to common environmental allergens (ALK-Abello A/S, Copenhagen, Denmark), as well as to metals, were carried out as described previously [9]. Histamine hydrochloride $\left(10 \mathrm{mg} \cdot \mathrm{mL}^{-1}\right)$ was used as the positive control. The concentrations of the tested metals in water solutions were the following: nickel sulphate $\left(10 \mathrm{mg} \mathrm{NiSO} 4 \cdot \mathrm{mL}^{-1}\right)$; potassium dichromate $\left(1 \mathrm{mg} \mathrm{Cr} \mathrm{Cr}^{6+} \cdot \mathrm{mL}^{-1}\right)$; chromium chloride $\left(1 \mathrm{mg} \mathrm{Cr} \mathrm{Cr}^{3+} \cdot \mathrm{mL}^{-1}\right)$; and cobalt chloride (1 mg $\left.\mathrm{Co}^{2+} \cdot \mathrm{mL}^{-1}\right)$.

\section{AFFILIATIONS}

*Dept of Occupational Medicine Finnish Institute of Occupational Health, Helsinki, and

\# Laboratory of Engineering Materials, Helsinki University of Technology, Espoo, Finland.

CORRESPONDENCE T. Hannu

Finnish Institute of Occupational Health

Topeliuksenkatu 41 a A

Fl-02500 Helsinki

Finland

Fax: 358304742149

E-mail: Timo.Hannu@ttl.fi

Received:

November 142004

Accepted after revision:

March 082005 
The diagnosis of OA was made according to the European guidelines [10]. The challenge tests were performed in an 8.5 $\mathrm{m}^{3}$ welding chamber. After completing the 30 -min welding challenge, patients were followed-up for $24 \mathrm{~h}$. Lung function measurements (forced expiratory volume in one second (FEV1)) were obtained using a portable, pocket-size spirometer (One Flow; STI MEDICAL, Saint-Romans, France). A drop in $20 \%$ of FEV1 was regarded significant, as compared with both the starting level and the control test. The clinical symptoms and lung auscultation findings were also recorded.

According to the steel production company (AvestaPolarit AB, Avesta, Sweden), the contents of 254 SMO® steel is as follows: chromium (19.5\%); nickel (17.5\%); and molybdenum $(6 \%)$. Whereas Duplex steel contains: chromium (21-24\%); nickel $(3.5-6 \%)$; and molybdenum $(0.1-3 \%)$. All the electrodes used were produced by ESAB AB (Gothenburg, Sweden). The electrodes contained: chromium ( 20\%); nickel (9-12\%); manganese $(0.5-0.8 \%)$; and molybdenum $(\sim 3 \%)$. An exception to this was the electrode used with SMO steel, which had $>60 \%$ nickel and $9.5 \%$ molybdenum. The electrode used with mild steel contained $\sim 1 \%$ manganese.

To determine the concentrations of the welding aerosols the challenge tests were repeated in identical conditions as the patients' specific challenge tests. The basic metals, the number of electrodes consumed, and the air exchange in the welding chamber were the same as in the challenge tests. The welding currents were those suggested by the manufacturer, ranging 120-150 A. During these tests, the air concentrations of the welding aerosols were determined from total dust and inhalable dust samples. The air concentrations of six metals were determined with the atomic absorption method. In these tests, a professional welding technician performed the welding with respiratory protection. These results are summarised in table 1.

\begin{tabular}{|c|c|c|c|c|}
\hline \multirow{2}{*}{$\begin{array}{l}\text { Measured dust } \\
\text { or metal }\end{array}$} & \multicolumn{4}{|c|}{ Welding of different steels } \\
\hline & Duplex & SMO & $\begin{array}{c}\text { Stainless } \\
\text { steel }\end{array}$ & Mild steel \\
\hline \multicolumn{5}{|c|}{ Personal sampling } \\
\hline Inhalable dust & 13.1 & 18.5 & 15.2 & 38.5 \\
\hline Total dust & 24.1 & 33.8 & 10.6 & 33.8 \\
\hline \multicolumn{5}{|l|}{ Area sampling } \\
\hline Total dust & 19.9 & 34.5 & 20.7 & 33.7 \\
\hline Aluminium $^{\#}$ & $0.63(4.8)$ & $1.7(9.2)$ & $0.53(3.5)$ & $0.1(0.3)$ \\
\hline Chromium $^{\#}$ & $0.51(3.9)$ & $0.98(5.3)$ & $0.54(3.6)$ & NA \\
\hline Iron $^{\#}$ & $0.59(4.5)$ & $0.03(0.2)$ & $0.49(3.2)$ & $6.0(15.6)$ \\
\hline Manganese $^{\#}$ & $0.38(2.9)$ & $0.15(0.8)$ & $0.32(2.1)$ & $1.8(4.7)$ \\
\hline Molybdenum $\#$ & $0.07(0.5)$ & $0.02(0.1)$ & $0.01(0.1)$ & NA \\
\hline Nickel $^{\#}$ & $0.02(0.2)$ & $0.09(0.5)$ & $0.02(0.1)$ & NA \\
\hline
\end{tabular}

Data are presented as $\mathrm{mg} \cdot \mathrm{m}^{-3}$ metal (per cent inhalable dust). NA: not analysed. ${ }^{\#}$ : in inhalable dust.

\section{CASES}

\section{Case 1}

A 46-yr-old male had been working as a welder since 1972 for the same employer, manufacturing machines for the pulp and paper industry. His work tasks consisted of welding (50\%) and assembly work (50\%), and he had used a motorised respiratory protective device during the past 3 yrs. In the industrial hall, general ventilation with local exhaust ventilation was in use.

The patient had no history of atopy, but his father had had asthma. He had smoked regularly during 1968-1981. In 1994, the patient had been examined because of dyspnoea, when mild hyperresponsiveness to histamine had been noted. In 1995, the diagnosis of obstructive sleep apnoea had been made.

In 1996, when the patient started welding 254 SMOß steel with the electrode OK 92.59, he experienced dry cough, severe dyspnoea and wheezing on the same evening. Other welders had welded the same steel in the industrial hall for 2 months. During the following 2 days, he had continued to weld SMO steel and the symptoms recurred. On the evening of the 3rd welding day, the symptoms were so severe that he went to the local hospital. He was treated with inhaled bronchodilators and was on sick leave for the next 2 weeks, during which time the symptoms subsided. Since then, the patient has not welded SMO steel, but has continued to weld stainless steel without any respiratory symptoms. In hospital, sprirometry and diffusion capacity were normal, but strong bronchial hyperresponsiveness to histamine was noted. Workplace PEF monitoring was not carried out.

At the Finnish Institute of Occupational Health (FIOH; Helsinki, Finland) in 1996, spirometry was normal and no hyperresponsiveness to histamine was noted. Diurnal PEF/ FEV1 values were within normal limits. Skin-prick tests to common allergens and metals were negative. Total serum immunoglobulin-E (IgE) was $254 \mathrm{kU} \cdot \mathrm{L}^{-1}$. Welding challenge tests with both mild steel using the electrode OK 48.00 and with common stainless steel using the electrode OK 63.30 were negative. Welding SMO steel with the electrode OK 92.59 caused a late asthmatic reaction, with a $37 \%$ maximum drop in FEV1 after the challenge test (fig. 1).

Avoidance of SMO welding was recommended, and inhaled salbutalmol on demand was prescribed. Since then, the patient has continued to work in the same workplace without welding SMO steel, but, in spite of this, has felt dyspnoea after work days. At the follow-up at FIOH 6 months later spirometry was normal, but his diurnal PEF/FEV1 values were suggestive of asthma, and inhaled budenoside was, therefore, started.

\section{Case 2}

A 34-yr-old male had worked as a welder since 1986 for the same employer as in case 1 . In the industrial hall, general ventilation with local exhaust ventilation was in use, and he had used a motorised respiratory protective device.

The patient had a history of atopy (rhinitis in association with cats and feather pillows) and his mother had had asthma. He had smoked regularly for several years, and was examined for dyspnoea in 1994 and again in 1999. In both instances spirometry and PEF monitoring were normal. 


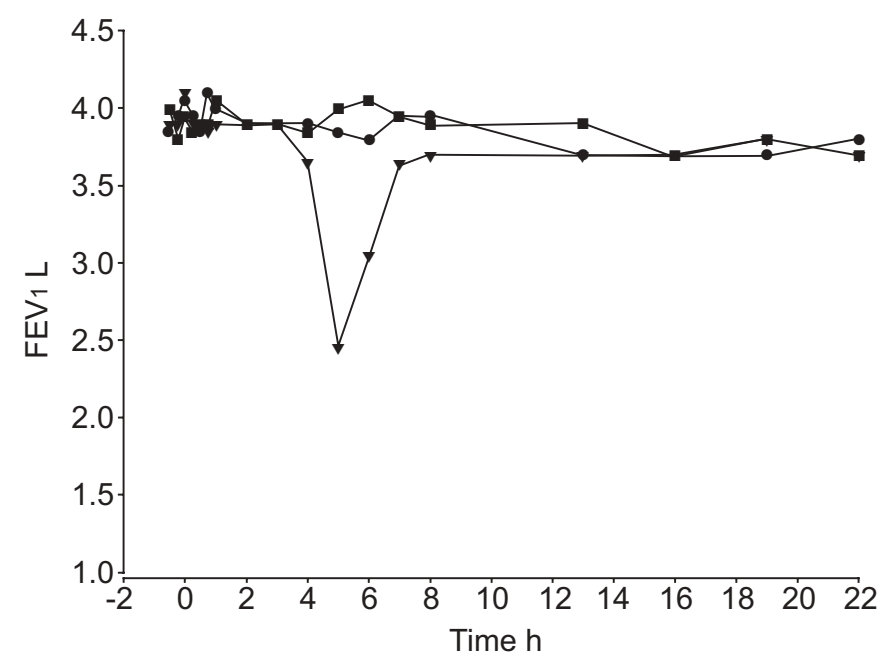

FIGURE 1. Forced expiratory volume in one second (FEV1) follow-up during challenge tests of case 1 with: $\mathbf{\square}$ : mild steel with OK 48.00; $\bullet$ : stainless steel with OK 63.30; $\mathbf{\nabla}$ : SMO steel with OK 92.59. Challenge occured at $0 \mathrm{~h}$.

During the 1990s the patient started to experience nasal congestion and, some years later, dyspnoea while welding.

At FIOH in 2001, spirometry was normal and no bronchial hyperresponsiveness to histamine was noted. Skin-prick tests to common allergens showed allergy to birch pollen, cat dander, dog dander and house dust mite, but tests to metals were negative. Total serum $\mathrm{IgE}$ was $88 \mathrm{kU} \cdot \mathrm{L}^{-1}$. The workplace PEF monitoring showed a variation of $500-680 \mathrm{~L} \cdot \mathrm{min}^{-1}$ during working days and $480-670 \mathrm{~L} \cdot \mathrm{min}^{-1}$ on days off. A diurnal variation $>20 \%$ was present on 6 working days compared to 1 day off. Inhaled fluticasone dipropionate was started for treatment of asthma.

Welding challenge tests with both mild steel using the electrode OK 48.00 and with stainless steel using the electrode OK 63.30 did not cause bronchial obstruction (fig. 2).

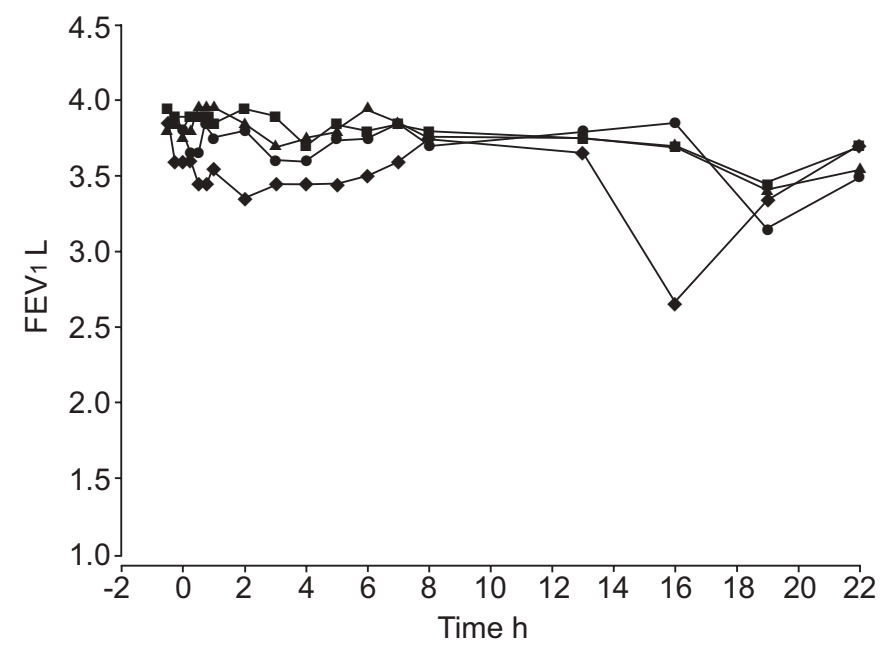

FIGURE 2. Forced expiratory volume in one second (FEV1) follow-up during challenge tests of case 2 with: $\mathbf{a}$ : mild steel with OK 48.00; $\bullet$ : stainless steel with OK 63.30; $\mathbf{\Delta}$ : mild steel; $\bullet$ : austenitic-ferritic (Duplex) steel with OK 67.50. Challenge occured at $0 \mathrm{~h}$.
Challenge tests were continued because the patient reported having dyspnoea especially when welding Duplex steel. Welding Duplex steel with the electrode OK 67.50 caused a late reaction, with a $31 \%$ maximum drop in FEV1 after the challenge test (fig. 2).

Avoidence of welding Duplex type steels was recommended and inhaled fluticasone dipropionate with salmeterol medication was continued. Since then, however, the measures at the workplace have not been effective enough to keep the patient's symptoms away and, therefore, occupational rehabilitation has been started.

\section{DISCUSSION}

Welding fumes consist of different gases and particles, depending on the composition of the welding electrodes, welded material and the welding method used. In both patients, the most notable differences in the electrodes used were the approximately six-times higher nickel content $(\sim 60 \%)$, as well as the three-times higher molybdenum content $(9.5 \%)$ in the electrode used with the SMO steel compared with the electrodes used with Duplex and stainless steel. According to the measurements obtained during simulated challenge tests, welding fumes of mild steel principally produced iron and manganese, whereas stainless steel produced a lesser amount of these, but a higher amount of chromium (table 1). These results are well in line with previous literature [11]. The composition of Duplex fumes was similar to that of stainless steel, but the former had somewhat higher proportions of chromium in the inhalable dust and also traces of molybdenum. Conversely, SMO fumes with a high content of chromium, and also of aluminium, differed from both the stainless steel and Duplex. There were also traces of nickel and molybdenum.

In subjects with OA due to stainless steel welding, chromium and/or nickel have been suggested to be the causative agents [3]. This hypothesis is supported by the fact that these metals are generated during welding of stainless steel, and have been documented to induce asthma in other occupations [12]. OA has also been reported in welders exposed to welding on aluminium [4]. In both patients, the chromium content of special steels was higher than that of stainless steel and, in the case of SMO steel, also the nickel content. Moreover, especially during SMO, but also during Duplex welding, the aluminium content was higher than that of stainless steel. These could be possible explanations for the asthmatic reactions induced by special steels, but not by stainless steel.

The pathophysiological mechanism responsible for the induction of OA in workers exposed to metals is unknown. In some studies an IgE-mediated mechanism has been proposed, although skin reactivity to metal salts has not been consistently demonstrated in subjects with OA caused by these agents [13]. The patients in the present study did not show immediate skin reactivity in skin-prick tests to chromium or nickel. Aluminium or molybdenum were not skin-prick tested, but they are not among the known inducers of IgE-mediated allergy. Also, the late nature of the challenge test reactions may point to mechanisms other than $\operatorname{IgE}$ mediation.

In conclusion, welding fumes of special steels can cause occupational asthma. This finding is important in view of the 
widespread use of these steels. Furthermore, the present results emphasise that there are differences between different steel subclasses in asthma inducibility.

\section{REFERENCES}

1 Sjögren B. Effects of gases and particles in welding and soldering. In: Zenz C, Dickerson OB, Horvath EP, eds. Occupational Medicine. St Louis, Mosby-Year Book Inc, 1994; pp. 917-925.

2 Antonini JM, Lewis AB, Roberts JR, Whaley DA. Pulmonary effects of welding fumes: review of worker and experimental animal studies. Am J Ind Med 2003; 43: 350-360.

3 Keskinen H, Kalliomäki P-L, Alanko K. Occupational asthma due to stainless steel welding fumes. Clin Allergy 1980; 10: 151-159.

4 Vandenplas O, Delwiche J-P, Vanbilsen M-L, Joly J, Roosels D. Occupational asthma caused by aluminium welding. Eur Respir J 1998; 11: 1182-1184.

5 Keskinen H, Pfäffli P, Pelttari M, et al. Chlorendic anhydride allergy. Allergy 2000; 55: 98-99.

6 Viljanen AA. Reference values for spirometric, pulmonary diffusing capacity and body plethysmographic studies. Scand J Clin Invest 1982; 42: Suppl. 159, 1-50.
7 Sovijärvi ARA, Malmberg LP, Reinikainen K, Rytilä P, Poppius H. A rapid dosimetric method with controlled tidal breathing for histamine challenge. Repeatability and distribution of bronchial reactivity in a clinical material. Chest 1993; 104: 164-170.

8 Burge PS. Single and serial measurements of lung function in the diagnosis of occupational asthma. Eur J Respir Dis 1982; 63: Suppl. 123, 47-59.

9 Kanerva L, Estlander T, Jolanki T. Skin testing for immediate hypersensitivity in occupational allergology. In: Menne T, Maibach, eds. Exogenous Dermatoses: Environmental Dermatitis. Boca Raton, Florida, CRC Press, 1991; 103-126.

10 Guidelines for the diagnosis of occupational asthma. Subcommittee on Occupational Allergy of the European Academy of Allergology and Clinical Immunology. Clin Exp Allergy 1992; 22: 103-108.

11 Sobaszek A, Boulenguez C, Frimat $\mathrm{P}$, Robin $\mathrm{H}$, Haguenoer JM, Edme J-L. Acute respiratory effects of exposure to stainless steel and mild steel welding fumes. $J$ Occup Environ Med 2000; 42: 923-931.

12 Chan-Yeung M, Malo JL. Aetiological agents in occupational asthma. Eur Respir J 1994; 7: 346-371.

13 Nemery B. Metal toxicity and the respiratory tract. Eur Respir J 1990; 3: 202-219. 